\title{
APLIKASI KONSENTRASI GULA TERHADAP KARAKTERISTIK MUTU MANISAN KECOMBRANG (Nicolaia spesiosa) BASAH DAN KERING
}

\author{
APPLICATION OF SUGAR CONCENTRATION ON QUALITY \\ CHARACTERISTICS OF WET AND DRY MANISAN \\ KECOMBRANG (Nicolaia spesiosa)
}

\author{
Berliandi, Eva Ramalia Sari \\ Program Studi Teknologi Pertanian Fakultas Pertanian \\ Universitas Dehasen Bengkulu \\ Email : evaramaliasari73@gmail.com
}

\begin{abstract}
ABSTRAK
Kecombrang (Nicolaia speciosa) merupakan tanaman rimpang yang kuncup bunga mudanya banyak dimanfaatkan sebagai sayuran karena banyak mengandung karbohidrat, serat pangan, lemak, protein, air, zat besi, fosforus, kalium, kalsium, magnesium, seng. Tujuan penelitian ini adalah untuk mengkarakterisasi mutu manisan bunga kecombrang basah dan kering. Penelitian ini menggunakan Rancangan Acak Lengkap (RAL) dengan menggunakan dua faktor beda, yaitu konsentrasi gula (30\%, 40\% dan 50\%) dan jenis manisan (basah dan kering), sehingga didapat 6 perlakuan. Masing - masing perlakuan dilakukan pengulangan sebanyak 3 kali. Analisis yang dilakukan meliputi kadar antioksidan, kadar serat dan organoleptik (warna, aroma, rasa dan tekstur). Hasil analisis kadar antioksidan dan kadar serat menunjukkan perbedaan yang nyata pada taraf signifikan $5 \%$. Kadar antioksidan manisan basah berkisar 2,19 ppm hingga 3,93 ppm dan manisan kering berkisar 4,59 ppm hingga 6,52 ppm. Kadar serat manisan basah berkisar 55,13\% hingga 60,14 \% dan manisan kering berkisar 69,25 \% hingga 75,49 \%. Hasil analisis tingkat kesukaan menunjukkan perbedaan yang nyata terhadap warna, rasa dan tekstur pada tingkat signifikan $5 \%$, dengan skala penilaian antara agak suka hingga suka. Sedangkan tingkat kesukaan terhadap aroma menunjukkan tidak berbeda nyata pada tingkat signifikan $5 \%$, dengan skala penilaian suka.
\end{abstract}

Kata kunci : manisan, kecombrang, antioksidan, serat

\section{ABSTRACT}

Kecombrang (Nicolaia speciosa) is a rhizome plant which young flower buds are used as vegetables because they contain a lot of carbohydrates, dietary fiber, fat, protein, water, iron, phosphorus, potassium, calcium, magnesium, zinc. The aim of this study was to characterize the quality of manisan kecombrang wet and dry. This study used completely randomized design (CRD) using two different factors, namely sugar concentration (30\%, 
$40 \%$ and 50\%) and types of sweets (wet and dry), thus obtained 6 treatments. Each treatment be repeated 3 times. Analysis was conducted on the levels of antioxidants, fiber content and organoleptic (color, flavor, taste and texture). The results of antioxidants and fiber content showed significant differences at the $5 \%$ significance level. The levels of manisan basah antioxidants ranges from 2.19 ppm until 3.93 ppm, and manisan kering ranges from 4.59 ppm until 6.52 ppm. Manisan basah fiber content ranges from $55.13 \%$ until $0.14 \%$ and manisan kering ranges from $69.25 \%$ until $75.49 \%$. Results of showed significant difference on the color, taste and texture to the significant level of 5\%, with the grading scale rather like until like. While organoleptic variable of flavor showed no significant difference at the $5 \%$ significance level, with the grading like.

Keywords: manisan, kecombrang, antioxidants, fiber

\section{PENDAHULUAN}

Kecombrang (Nicolaia speciosa) merupakan tanaman rimpang yang kuncup bunga mudanya banyak dimanfaatkan sebagai sayuran karena banyak mengandung karbohidrat, serat pangan, lemak, protein, air, zat besi, fosforus, kalium, kalsium, magnesium, dan seng (Hidayat dan Hutapea 1991). Selain itu bunga kecombrang memiliki bentuk, warna, aroma, dan rasa yang khas. Bentuk bunga kecombrang menyerupai jantung pisang dengan warna pink. Aroma bunga kecombrang harum pedas karena mengandung senyawa alkaloid, flavonoid, polifenol, steroid, saponin, dan minyak atsiri (Jaffar et al., 2007).

$$
\text { Selain dimanfaatkan sebagai }
$$

kuliner, bunga kecombrang juga dapat dimanfaatkan sebagai tanaman herbal karena dapat memperlancar ASI, menurunkan tekanan darah, anti kanker, antioksidan, dan masih banyak lagi khasiatnya yang belum diketahui (Anonim, 2013).

Namun tidak sedikit masyarakat Indonesia yang belum mengenal tanaman ini karena masih bersifat tanaman liar. Disamping itu, belum adanya pemanfaatan tanaman ini sebagai produk olahan yang dapat memperpanjang umur simpannya. Salah satu produk olahan yang dapat dibuat adalah manisan bunga kecombrang, baik manisan basah maupun manisan kering. Dengan demikian, diharapkan tanaman kecombrang akan semakin banyak dikenal oleh masyarakat luas dan pemanfaatanya sebagai bahan pangan dapat lebih dioptimalkan. Penelitian ini bertujuan untuk mengetahui pengaruh konsentrasi gula terhadap antioksidan, kadar serat dan sifat organoleptik dalam pembuatan manisan bunga kecombrang basah dan kering.

\section{METODE PENELITIAN}

\section{Alat dan Bahan}


Alat yang digunakan dalam penelitian ini adalah baskom, pisau, talenan, panci, timbangan, toples, kompor, pengaduk, saringan, gelas ukur. Sedangkan bahan yang digunakan dalam penelitian ini adalah bunga kecombrang, gula pasir, air , dan garam.

\section{Rancangan Percobaan}

Perlakuan percobaan yang digunakan dalam penelitian ini adalah Rancangan Acak Kelompok (RAK) dengan menggunakan dua faktor beda, yaitu jenis manisan (manisan basah dan manisan kering), dan kosentrasi gula, dengan 6 perlakuan dan 3 ulangan. Perlakuan yang digunakan adalah manisan basah kecombrang konsentrasi gula 30\% (M1G1), manisan basah kecombrang konsentrasi gula 40\% (M1G2), manisan basah kecombrang konsentrasi gula 50\% (M1G3), manisan kering kecombrang konsentrasi gula 30\% (M2H1), manisan kering kecombrang konsentrasi gula 40\% (M2H2), manisan kering kecombrang konsentrasi gula 50\% (M2H3).

\section{Pelaksanaan Penelitian}

\section{Pembuatan Manisan Basah Bunga}

\section{Kecombrang}

Langkah - langkah yang dilakukan pada tahap ini ialah bunga kecombrang sebanyak $1 \mathrm{~kg}$ dilakukan pengupasan kelopak. Pencucian pertama dengan air bersih dan ditiriskan kemudian dilakukan pembelahan. Perendaman dalam larutan garam 10\% selama 5 jam dalam 1 liter air. Dilakukan pencucian kedua. Pembuatan larutan gula (30\%, 40\%, dan 50\%) dan Perendaman dalam larutan gula (30\%, $40 \%$ dan 50\%) selama 24 jam. Perebusan dalam larutan gula $(30 \%, 40 \%$ dan $50 \%)$ sehingga menjadi manisan kecombrang basah.

\section{Pembuatan Manisan Kering Bunga Kecombrang}

Langkah - langkah yang dilakukan pada tahap ini adalah bunga kecombrang sebanyak $1 \mathrm{~kg}$ dilakukan pengupasan kelopak dan pencucian pertama, kemudian dilakukan pembelahan bunga kecombrang. Perendaman dalam larutan garam $10 \%$ selama 5 jam, lalu dilakukan pencucian kedua. Pembuatan larutan gula (30\%, 40\% dan 50\%) dan perendaman dalam larutan gula selama 24 jam. Perebusan dalam larutan gula (30\%, 40\% dan 50\%). Penirisan dan dilakukan penaburan dengan gula pasir sehingga menjadi manisan kecombrang kering.

\section{Analisis Penelitian \\ Masing-masing perlakukan dilakukan analisis antioksidan, kadar serat, uji organoleptik dengan 20 orang panelis agak terlatih. Data yang diperoleh}


dianalisis dengan menggunakan analisis sidik ragam pada taraf $5 \%$.

\section{HASIL DAN PEMBAHASAN}

\section{Kadar Antioksidan Manisan Basah}

dan Manisan Kering Bunga

\section{Kecombrang}

Nilai rerata analisis terhadap kadar antioksidan manisan basah bunga kecombrang dengan perlakuan konsentrasi gula $(30 \%, 40 \%$ dan $50 \%)$ dan manisan kering bunga kecombrang bersalut gula dengan perlakuan konsentrasi gula (30\%, 40\% dan 50\%) dapat dilihat pada tabel 1.

Hasil analisis kadar antioksidan menunjukkan perbedaan yang nyata pada taraf signifikan 5\%. Kadar antioksidan manisan basah berkisar 2,19 ppm hingga 3,93 ppm dan manisan kering berkisar 4,59 ppm hingga 6,52. Semakin tinggi kadar gula yang ditambahkan semakin rendah aktivitas antioksidan yang terkandung dalam manisan bunga kecombrang. Hal ini disebabkan karena kerusakan antosianin dan vitamin C semakin meningkat sejalan dengan penambahan gula dalam manisan bunga kecombrang. Diketahui bahwa antosianin dan vitamin $\mathrm{C}$ merupakan substansi yang dapat berperan sebagai antioksidan. Menurut Ardiyansyah (2007), antioksidan adalah substansi yang dapat menurunkan radikal bebas dan stress oksidatif.

\section{Kadar Serat Manisan Basah dan \\ Kering Bunga Kecombrang}

Nilai rerata analisis terhadap kadar serat manisan basah bunga kecombrang dengan perlakuan konsentrasi gula (30\%, $40 \%$ dan 50\%) dan manisan kering bunga kecombrang bersalut gula dengan perlakuan konsentrasi gula $(30 \%, 40 \%$ dan 50\%) dapat dilihat pada tabel 2 .

Hasil analisis kadar serat menunjukkan perbedaan yang nyata pada taraf signifikan $5 \%$. Kadar serat manisan basah berkisar 55,13\% hingga 60,14\% dan manisan kering berkisar 69,25\% hingga $75,49 \%$.

Sifat Organoleptik Warna, Aroma, Rasa, dan Tekstur Manisan Basah dan Manisan Kering Bunga Kecombrang

Hasil analisis tingkat kesukaan menunjukkan perbedaan yang nyata terhadap warna, rasa dan tekstur pada tingkat signifikan $5 \%$. Perlakuan konsentrasi gula $(30 \%, 40 \%$ dan 50\%) pada manisan basah bunga kecombrang dan manisan kering bunga kecombrang berpengaruh terhadap warna manisan yang dihasilkan. Warna yang paling disukai oleh panelis yaitu perlakuan konsentrasi gula $30 \%$ dan $40 \%$ pada manisan kering yaitu dengan skor penilaian 3,85 (suka). Perubahan warna pada manisan kering bunga kecombrang disebabkan oleh larutan gula, menurut 
Tabel 1. Analisis Kadar Antioksidan (ppm) Manisan Basah dan Manisan Kering Bunga Kecombrang

\begin{tabular}{ccc}
\hline & \multicolumn{2}{c}{ Kadar Antioksidan $(\mathrm{ppm})$} \\
\cline { 2 - 3 } Gula $(\%)$ & Manisan Basah & Manisan Kering \\
\hline 30 & $58.12 \mathrm{e}$ & $75,49 \mathrm{a}$ \\
40 & $55.13 \mathrm{f}$ & $71,65 \mathrm{~b}$ \\
50 & $60.14 \mathrm{~d}$ & $69,25 \mathrm{c}$ \\
\hline
\end{tabular}

Ket : Angka yang diikuti dengan kode huruf yang berbeda menunjukkan adanya perbedaan yang nyata pada taraf signifikan $5 \%$.

Tabel 2. Analisis Kadar Serat (\%) Manisan Basah dan Manisan Kering Bunga Kecombrang

\begin{tabular}{ccc}
\hline & \multicolumn{2}{c}{ Kadar Serat $(\%)$} \\
\cline { 2 - 3 } Gula $(\%)$ & Manisan Basah & Manisan Kering \\
\hline 30 & $2,57 \mathrm{~b}$ & $6,52 \mathrm{a}$ \\
40 & $2,19 \mathrm{~b}$ & $5,68 \mathrm{ab}$ \\
50 & $3,93 \mathrm{ab}$ & $4,59 \mathrm{ab}$ \\
\hline
\end{tabular}

Ket : Angka yang diikuti dengan kode huruf yang berbeda menunjukkan adanya perbedaan yang nyata pada taraf signifikan $5 \%$.

Tabel 3. Analisis Organoleptik Warna Manisan Basah dan Manisan Kering Bunga Kecombrang

\begin{tabular}{ccccc}
\hline & \multicolumn{4}{c}{ Sifat Organoleptik } \\
\cline { 2 - 5 } Gula (\%) & Warna & Aroma & Rasa & Tekstur \\
\hline Manisan Basah & & & & \\
30 & $3,4 \mathrm{ab}$ & $3,8 \mathrm{ab}$ & $3,8 \mathrm{a}$ & $4 \mathrm{a}$ \\
40 & $3,55 \mathrm{ab}$ & $3,7 \mathrm{ab}$ & $3,9 \mathrm{a}$ & $3,75 \mathrm{ab}$ \\
50 & $3,45 \mathrm{ab}$ & $3,6 \mathrm{~b}$ & $3,95 \mathrm{a}$ & $3,65 \mathrm{ab}$ \\
Manisan Kering & & & & \\
30 & $3,85 \mathrm{a}$ & $3,95 \mathrm{a}$ & $3,8 \mathrm{a}$ & $3,7 \mathrm{ab}$ \\
40 & $3,85 \mathrm{a}$ & $3,75 \mathrm{ab}$ & $3,9 \mathrm{a}$ & $3,6 \mathrm{~b}$ \\
50 & $3,1 \mathrm{~b}$ & $3,75 \mathrm{ab}$ & $3,4 \mathrm{~b}$ & $3,3 \mathrm{~b}$ \\
\hline
\end{tabular}

Ket : Angka yang diikuti dengan kode huruf yang berbeda menunjukkan adanya perbedaan yang nyata pada taraf signifikan $5 \%$.

Ket. Skala : $1=$ sangat tidak suka; $2=$ tidak suka; $3=$ agak suka; $4=$ suka; $5=$ sangat suka 
Winarmo (1997), gula yang dipanaskan akan berubah menjadi coklat. Menurut Falade, et al (2007), pigmen alami merupakan senyawa alami yang tidak stabil dan mudah pecah selama proses pengolahan dengan pemanasan.

Perlakuan konsentrasi gula 30\%, 40\% dan $50 \%$ pada manisan basah tidak berpengaruh terhadap rasa manisan yang dihasilkan. Perlakuan konsentrasi gula (30\%, 40\% dan 50\%) pada manisan kering berpengaruh terhadap rasa manisan yang dihasilkan. Perlakuan gula 50\% pada manisan basah dan 50\% pada manisan kering menunjukkan lebih disukai oleh panelis dibandingkan perlakuan yang lain. Hal ini dikarenakan gula dapat berfungsi sebagai bahan penambah rasa, bahan perubah warna dan bahan untuk memperbaiki susunan dalam jaringan (Subagjo, 2007). Rasa suatu bahan makanan umumnya dipengaruhi oleh rasio gula dan asam yang terdapat dalam bahan makanan tersebut (Djajati, dkk, 2012).

Perlakuan konsentrasi gula dan jenis manisan (basah dan kering) bunga kecombrang menunjukkan pengaruh yang nyata terhadap tekstur manisan. Perlakuan konsentrasi gula $30 \%$ pada manisan basah bunga kecombrang paling disukai diantara perlakuan lainnya yaitu dengan skor penilaian 4 (suka).

Hasil analisis tingkat kesukaan terhadap aroma menunjukkan tidak berbeda nyata pada tingkat signifikan $5 \%$. Hal ini menandakan bahwa perlakuan konsentarsi gula $(30 \%, 40 \%$ dan 50\%) pada manisan basah bunga kecombrang dan manisan kering bunga kecombrang tidak berpengaruh terhadap aroma manisan yang dihasilkan. Hal tersebut dikarenakan bunga kecombrang memilki senyawa volatil yang khas dan senyawa ini memberikan aroma khas pada bunga kecombrang. Meskipun sudah mengalami proses pengolahan dan pemanasan aroma khas bunga kecombrang pada manisan basah maupun manisan kering masih ada.

\section{KESIMPULAN}

Dari hasil penelitian dapat disimpulkan bahwa bunga kecombrang mempunyai potensi yang tinggi untuk diolah menjadi manisan, baik manisan basah maupun manisan kering. Hasil analisis kadar antioksidan dan kadar serat menunjukkan perbedaan yang nyata pada taraf signifikan $5 \%$. Kadar antioksidan manisan basah berkisar 2,19 ppm hingga 3,93 ppm dan manisan kering berkisar 4,59 ppm hingga 6,52 ppm. Kadar serat manisan basah berkisar 55,13 \% hingga $60,14 \%$ dan manisan kering berkisar $69,25 \%$ hingga $75,49 \%$. Hasil analisis tingkat kesukaan menunjukkan perbedaan yang nyata terhadap warna, rasa dan tekstur pada tingkat signifikan $5 \%$, dengan skala penilaian antara agak suka 
hingga suka. Sedangkan tingkat kesukaan terhadap aroma menunjukkan tidak berbeda nyata pada tingkat signifikan $5 \%$, dengan skala penilaian suka. Dengan demikian, perlakuan konsentrasi gula berpengaruh nyata terhadap peningkatan kadar antioksidan, kadar serat, sifat organoleptik (warna, rasa, dan tekstur) pada manisan basah dan manisan kering kecombrang. Akan tetapi, tidak berpengaruh nyata terhadap aroma manisan basah dan manisan kering kecombrang.

\section{DAFTAR PUSTAKA}

Anonim. 2013. Produksi Hasil Nabati.Kemendikbud. Jakarta.

Ardiyansyah. 2007. Antioksidan dan Peranannya bagi Kesehatan. Artikel Iptek. Akses: 22 April $2010 . \quad \mathrm{http} / /$ ardiyansyah. multiply.com/journal/item/ 14?\&item_id=14\&view:replies=r everse
Djajati, S., Sarofa, U., dan Syamsul, A. 2012. Pembuatan Nata de Manggo : Kajian Konsentrasi Sukrosa dan Lama Fermentasi. Jurusan Teknologi Pangan. FTIUPN, Jawa Timur

Falade, K. O., Igbeka, J.C., Ayanwuyi, F.A., 2007. Kinetics of Mass Transfer and Colour Changes During Osmotic Dehydration of Watermelon. Journal Food Engineer. 80 (3), 979-985.

Hidayat, S.S dan Hutapea Jr. 1991. Inventaris Tanaman Obat Indonesia. Edisi I: 440-441. Badan Penelitian dan Pengembangan Departemen Kesehatan Republik Indonesia.

Jaffar, F. M., C.P. Osman, N. H. Ismail dan K. Awang. 2007. Analysis of essential oils of leaves, stems, flowers and rhizomes of Etlingera Elatior (JACK) R. M. SMITH. The Malaysian Journal of Analytical Sciences, Vol. 11 : 269-273.

Subagjo, A., 2007. Manajemen Pengolahan Roti dan Kue. Graha Ilmu, Yogyakarta.

Winarno, 1997. Kimia Pangan dan Gizi. PT. Gramedia, Jakarta. 